Suchanek, P., Kralova, M. (2018). The Influence of Costumers' Personal Characteristics on their Satisfaction with the Food Industry. Journal of Competitiveness, 10(4), 151-170. https://doi.org/10.7441/ joc. 2018.04 .10

\title{
THE INFLUENCE OF CUSTOMERS' PERSONAL CHARACTERISTICS ON THEIR SATISFACTION WITH THE FOOD INDUSTRY
}

\section{- Petr Suchanek, Maria Kralova}

\begin{abstract}
The subject of this research is the influence of numerous factors and variables on customer satisfaction, which is one of the main factors of the company's competitiveness. The objective of the study, therefore, is to ascertain which factors and variables influence customer satisfaction and, as a result, the competitiveness of the enterprise from within the food industry. The research has been conceived in two successive steps. The first of these is to discover the influence of selected factors on customer satisfaction. Amongst these were factors which not only sometimes clearly influenced customer satisfaction (factors of customer satisfaction), but also factors which clearly influenced other types of satisfaction which were then associated with customer satisfaction (personal characteristics). In the second step, mutual relationships between the two groups of factors is described. The research was carried out on a sample of firms in the food industry along with their end customers. Multiple regression and a hierarchical mixed-effect model with the appropriate statistical tests were used for modelling. From the results it emerges that only the factors of customer satisfaction (customer expectation, perceived quality and perceived value) have an effect on overall customer satisfaction. The influence of personal characteristics was not proven. However, a (weak) relationship was shown between some of the factors of customer satisfaction (perceived value, perceived quality, competitiveness and customer expectation) and a number of factors from the group of personal characteristics (financial capacity, level of optimism and level of planning).
\end{abstract}

Keywords: customer satisfaction, factors of customer satisfaction, competitiveness, personal characteristics, demographic characteristics

JEL Classification: L66, M31

Received: April, 2018

1st Revision: October, 2018

Accepted: October, 2018

\section{INTRODUCTION}

The subject of this study is research into customer satisfaction (CS) in the context of customers' personal characteristics. This article is based on the assumption that personal characteristics (PC) influence satisfaction as well as how satisfaction is viewed by the customer. Our assump- 
tion is based on the finding that 'the nature and extent of response bias in satisfaction ratings varies by customer characteristics' (Mittal \& Kamakura, 2001).

Satisfaction in the general sense of the word can be understood as life satisfaction, which can be defined as 'a person's appraisal of the relative quality of his or her life. Life satisfaction is a summary view of the person's life overall.' (Hofmann et al., 2014). Therefore, satisfaction is a general term incorporating various types. Life satisfaction is a subjective feeling of wellbeing connected to overall happiness in life (Lent et al., 2005) and is either positively or negatively influenced by various factors, e.g. personality traits, cognitive processes, behavioural characteristics (Azizli et al., 2015).

Numerous studies have linked CS to the subjective quality of life of the product user (Neal \& Gursoy, 2008). In a study by Neal \& Gursoy, the product user is the tourist, and the product is a service, i.e. travelling or tourism. Other authors have discussed tourism satisfaction, which, as above, is connected to life satisfaction (Chen et al., 2016) in the sense that satisfaction with travel service has a direct impact on this subjective feeling (Neal et al., 2007). If there is a relationship between CS, services and the life satisfaction of this customer, it may then be deduced that a relationship may also exist between CS and the product (or products generally) and the life satisfaction of this customer.

Financial satisfaction can be defined as the subjective evaluation of a financial position which is closely connected to the subjective feeling of wellbeing (Vera-Toscano et al., 2006). Therefore, this satisfaction, or rather the factors that it influences, may also influence CS.

As with other forms of satisfaction, CS is influenced by a number of factors. As shown in Fig. 1, it is possible to construct a model which indicates the relationship between the variables examined. It is clear from the model that there are numerous different factors which influence various forms of satisfaction (life, financial and CS). The relationships indicated by a full arrow are from the literature search shown below. The relationships indicated by a dashed arrow represent those relationships which have been verified by the present research.

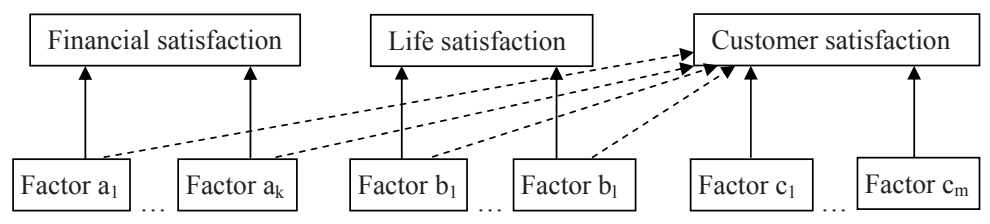

Fig. 1 - Model of factors influencing different types of customer satisfaction. Source: authors

Fig. 1 poses the question as to whether there is a relationship (and if so, what kind) between the factors influencing life and financial satisfaction and CS. Part of the research was to verify that the factors influencing financial and life satisfaction also influence CS (whether directly or indirectly through the factors which clearly influence CS). Therefore, the objective of the paper is to determine which of the selected factors influencing the various forms of satisfaction directly or indirectly influence CS. 


\section{THEORETICAL FRAMEWORK}

Customer expectation (CE) also plays an important role in a customer's assessment of foods (Cardello, 1995). Research has shown that different levels of expectation have an influence on assessing the quality level of food products (cf. Tuorila et al., 1994). At the same time, 'expectation is based on the customer's needs and wishes' (Edvardsson \& Olsson, 1996). An important part of customer expectations also takes the form of the establishment and filfillment of promises, although the literature looks more at services in this regard (cf. Ojasalo, 2001).

$\mathrm{CE}$ is also closely related to perceived product quality (see below). In relation to food, the customer expects quality from a sensory perspective (taste, sight, touch), in terms of health (nutritional and microbiological quality), convenience as well as the process (ecological-organic, natural produce, animal protection, genetically modified crops, etc). (Brunsø et al., 2002, which represents the same perception of quality used in a model by Grunert, 2005). With the purchase of a product, CE becomes an experience which is reflected in the perceived quality of the product, and with repeated purchase both the customer's expectation and the perceived quality of the product can change (Grunert, 2005). Therefore, the stability level of CE is an interesting variable connected to perceived product quality and customer satisfaction.

Perceived quality (PQ) can be defined as 'the customer's perception of the overall quality or superiority of the product or service with respect to its intended purpose, relative to the alternatives' (Aaker, 1991). 'The PQ (as consumers' overall quality evaluation) is the result both of the expected quality and the experienced quality' (Poulsen et al., 1996).

Food quality is understood as good nutritional, microbiological and textural quality (Cardello, 1995). Textural quality incorporates the mechanical, geometrical and surface qualities of the product, perceivable through mechanical, tactile and sight and sound receptors, which can be considered to evaluate sensory quality (cf. Cardello, 1995). However, in addition to sensory attributes, as part of PQ, an expected level of safety, utility, cost, etc. must also be present (Cardello, 1995), after which it is possible to discuss the overall perceived quality of the product as described above by Poulsen (1996). A similar view, albeit within the framework of differently structured characteristics, was also presented by Ophuis \& Van Trijp (1995).

'Customer Perceived Value (PV) can be defined as the result of the personal comparison between perceived overall benefits and the perceived sacrifices or costs paid by the customer' (Zeithaml, 1988). 'A customer's PV represents an overall mental evaluation of a particular good or service' (Yang, Peterson, 2004). The research demonstrates that customer PV can be measured as the ratio of quality and price in which a trade-off exists between quality and price, i.e. to combine a certain level of quality with a certain price. It was also discovered that if the customer perceives the value of a product as high, then there is also a relatively high probability that they will actually buy the product (Zeithaml, 1988; Monroe, 2002).

PV can be measured as a single- or multi-component variable (cf. Woodruff \& Gardial, 1996). A multi-component approach contains several variables in the PV: the customers' functional, economic, emotional and social value perceptions (Floh, et al., 2014). In our research, we also concentrated on a list of aspects related to functional and economic value which we constructed in accordance with Sweeney \& Soutar (2001): 
- price/value for money (the utility derived from the product due to the reduction of its perceived short-term and longer-term economic value)

- performance/quality (the utility derived from perceived quality and the expected performance of the product, i.e. functional value).

CS is related to the Competitiveness (C) of the product or company, so it is also appropriate for the research to focus on this aspect. 'Customer satisfaction with a company's products or services is often seen as the key to a company's success and long-term competitiveness' (Henning-Thurau \& Klee, 1997). 'Company competitiveness refers to its ability to design, produce, and (or) market products superior to those offered by competitors, considering the price and nonprice qualities' (El-Diraby et al., 2006). In identifying the variables which can measure C, it is possible to use the consumer's buying decision model created by Dubrovski (2001). In our case, C was understood on three levels: on a company level (with a focus on the brand), on a product level (with a focus on quality and marketing communication) and on the level of (perceived) cost (Dubrovski, 2001). Our research was restricted to one country, the Czech Republic.

CS is also based on customer knowledge, which 'is about products, suppliers and markets' (Aghamirian et al., 2015) as well as 'customer trends and future needs, and ideas for product innovations' (Desouza \& Awazu, 2005). For the requirements of our research, we narrowed down the scope of this information to Product Knowledge (PK).

'The literature identifies two types of satisfaction: transactional and overall (or cumulative) satisfaction' (Spitery \& Dion, 2004). In our research, we focused on cumulative Customer Satisfaction (CS), which can be defined as the overall experience with a purchase, as general satisfaction (cf. Fornell, 1992). Cumulative satisfaction can be understood as long-term and based on repeated purchases as well as on the customer's overall experience with the product, including their assessment of the retailing or supplying party (not only the producer, but also the retailer). CS was, therefore, measured in accordance with Fornell using three indicators: general satisfaction, confirmation of expectations, and the distance from the customer's hypothetical ideal product (Fornell, 1992).

Personal Characteristics influence the consumption and volume of purchases (Tarasi et al., 2013). Therefore, it can be assumed that these features will also influence a company's revenue and profits, i.e. its performance, while from the company's perspective it is useful not only to recognize these characteristics of its customers, but also to influence them in order to increase the company's revenues and profits. PC which are used most often in customer-satisfaction research are age and income (cf. Tarasi et al., 2013), with gender also appearing frequently (cf. Anderson et al., 2008). Some researchers (e.g. Peterson \& Ekici, 2007) describe these variables as demographic characteristics. Due to the large number of variables of PC and the methodology for carrying out the research, we will term the group of variables of age, income and gender as demographic characteristics, and the group of variables Personality 1-7 (see below) as PC.

Financial satisfaction is closely connected to financial capacity, which has been described as the ability to effectively manage economic resources to attain wellbeing (Xiao et al., 2014). To measure financial capacity, we used the variables Personality 1-3 (adequate monthly income, access to the purchase of cheap products, reserve for unexpected expenditure) which were constructed on the basis of questions used in research by Taylor (Taylor, 2011). 
The research shows that satisfaction may be influenced by emotions (albeit with a combination of other factors), as well as personal disposition (optimist or pessimist) (cf. Westbrook, 1980). Optimism can be defined as 'one's general expectation of successful and favourable outcomes' (Dixon \& Schertzer, 2005). Level of optimism can be included among personality traits, and research has shown a connection between optimism and life satisfaction (Ho et al., 2010). Personality 4 variables were used to measure the level of optimism.

The research has demonstrated that life satisfaction is also connected to planning, i.e. whether and how the person in question plans (Azizli et al., 2015; Prenda \& Lachman, 2001). Therefore, we also decided to include this factor in our research. 'Planning is a life management strategy which allows individuals to structure and to manifest control in their lives' (Prenda \& Lachman, 2001). For future planning, or the level of future planning, we used the variables Personality 5 (fullness of the fridge) and Personality 6 (frequency of shopping).

Numerous studies have also examined the attitudes of customers towards marketing (e.g. Chan, Cui, 2004) and advertising (e.g. Haghirian \& Madlberger, 2005), and their influence on CS. It was discovered that customers' attitudes towards marketing had an influence on CS, and also that customers' attitudes towards marketing was less critical (in general) in transitional economies (Chan, Cui, 2004). It was also discovered that customers' attitudes towards marketing (advertising) were related to life satisfaction (cf. Peterson \& Ekici, 2007). Customers' attitudes towards marketing (advertising) could also be a factor which is connected to both life satisfaction and CS. The variable Personality 7 focuses on customers' attitudes (the level of criticism) towards marketing (specifically advertising).

Therefore, we will work with a total of two groups of variables in the research, the first of which is made up of factors of CS consisting of the variables: PK, CE, PQ, PV and C. The second group of variables is made up of PC represented by the seven variables Personality 1-7, along with the demographic characteristics represented by the three variables of gender, age and income. The main independent variable which we want to model is the CS variable.

\section{METHODOLOGY}

The research made use of a questionnaire consisting of thirty-two scaled questions which was presented to the respondents-customers. With the exception of the variables sex, age and income, all of the questions were constructed as variables scaled from 1-10. A value of 1 signified a low evaluation by the respondent, i.e. a low level of satisfaction, while a value of 10 signified a high evaluation by the respondent. Owing to the subsequent statistical evaluation of the results, these questions were constructed in the same direction so that a higher value always meant a better evaluation of the company. In a multiple regression, CS was modelled via the following variables: $\mathrm{PK}, \mathrm{CE}, \mathrm{PQ}, \mathrm{PV}$ and $\mathrm{C}$, with a control on variables of personal characteristics (output shown in Table 1a and 1b). The variables CS, PQ, PV, CE and C were constructed as means of related questions from the questionnaire (e.g. C is a mean of scores on C1, C2, C3, C4).

The question focusing on the sex variable was binary (man $x$ woman). The question for the monthly income variable was scaled with values of 1-8, wherein a value of 1 corresponded to an income of up to 5,000 CZK (approx. 192 EUR) and a value of 8 was an income greater than 
35,000 CZK (approx. 1,346 EUR). The scale was therefore graded over 5,000 CZK (approx. 192 EUR). The question focusing on the age variable was scaled with values of 1-9, where value 1 included respondents aged 18-20 and value 9 contained respondents aged 56 and above. The scale for 2-8 was graded over 5 years (i.e. level 2 contained respondents aged 21-25).

\subsection{Statistical methodology}

As part of the research, several models were designed based on the questionnaires for the companies' customers. To model CS, we used both the traditional multiple linear regression model (Gelman \& Hill, 2006), as well as the hierarchical mixed-effects model (Gelman, Hill, 2006, Raudenbush, Bryk, 2002). The canonical Correlation Analysis was used to model the relationship between the set of variables representing factors of CS and the set of variables representing PC and demographic characteristics.

Among other features, the traditional multiple regression model assumes the independence of cases. However, if the cases can be sorted into groups with regard to the level of the 'higher unit', the independence of individual cases cannot be assumed in the event that the group has an actual effect on the dependent variable. In such a situation, it is necessary to consider the use of a multilevel hierarchical model. In our research, the level of the group corresponds to the companies, and the level of the cases corresponds to the respondents.

The respondents evaluating one company form one group (15 respondents), with the number of groups equalling the number of companies (in our case 102 companies from the food industry). Each respondent assessed only one company. The effects in the hierarchical model can be either fixed (in the traditional multiple regression model, the effects are always fixed), or random. In terms of the character of the data and the nature of the research, the model contains those effects which are estimated to be fixed as well as those which are random. In our research, we set the effect of the group (i.e. of the company) as a random effect, and the effects of the individual explanatory variables (the two factors of satisfaction as well as the PC and demographic characteristics) as fixed. The model can, therefore, be loosely described as:

The overall satisfaction of the respondent i from the group of respondents evaluating the companies $j=$ the average satisfaction across the whole population + the random error of the company $j+$ the random error of the respondent $i$ from the group of respondents evaluating the companies $j+$ the fixed effects of the other explanatory variables

The ICC (intra-class correlation coefficient) then indicates which part of the variability of the dependent variable (overall CS) can be attributed to the effect of the group (company).

The canonical Correlation Analysis generalizes the correlation analysis between the two scalar variables with an analysis of the level of association between the two sets of variables. Each of the two sets of variables is represented by its representative (or more precisely the sequence of representatives) and subsequently the correlation between these representatives of the two sets is determined. Such correlations are termed canonical correlations, and the sets of unobservable representatives are termed canonical variables. The canonical variable from the particular set corresponds to the linear combinations of variables in this set in order to match as closely as possible the canonical variable of the second set. This produces the first pair of canonical variables which corresponds to the first canonical correlation coefficient. Naturally, the correlation 
of the first pair of canonical variables does not exhaust the overall association between both sets, and so it is possible to construct other pairs of canonical variables. The number for all of the pairs of canonical variables is the same as the number of variables in the smaller set. Of course, not all of the canonical correlation coefficients have to be statistically significant. Those pairs of canonical variables of which correlation coefficient is statistically significantly different from zero are interesting for analysis and interpretation. Even more interesting than the canonical correlation coefficients is 'redundancy'. This indicates how the variability of one set is explained by the second set (or more precisely, by the canonical variables of the second set). The greater the value of redundancy, the more that the variability of one set can be explained by the second set. Redundancy takes values from the interval (0.1) or $0 \%-100 \%$. The canonical correlation was used to assess the association between the set of variables corresponding to the factors of CS and the set of variables corresponding to PC and demographic characteristics.

\subsection{Characteristics of the research sample}

The research was carried out on a sample of 1,530 customers of food-industry companies from the Czech Republic in spring 2016. This was a representative sample of respondents from the population of the Czech Republic in terms of age (18+), gender and region, and was selected randomly. The selection of the sample was complicated because it was necessary to randomly select the respondents who had experience with the practice with the product of a real enterprise and at the same time to ensure the representativeness of the selection in view of the above mentioned characteristic of the Czech Republic population. In terms of the type of sampling method used, therefore, it was a random stratified selection.

The sample of food-industry companies contained 102 companies. Specifically, these were companies from the manufacture of food and beverage products which manufacture products for everyday consumption (which are well known among consumers).

\subsection{Models and research questions}

Based on a study of the above-mentioned literature and the existing research, the authors outlined the variables which could potentially influence CS. These variables reflect both the individual factors of CS (the group of factors of CS), and its PC and demographic characteristics which might be relevant for CS (the group of variables of PC and demographic characteristics). Therefore, the first stage of the research focuses on discovering which of these three groups of variables has a significant influence on CS and to what degree. Fig. 2a is used to illustrate the modelled relationships.

Based on the model shown in Fig. 2a, the first research question (RQ1) can be formulated:

Which specific variables from the two groups of variables influence CS?

This general research question can be then made more specific in two more detailed research questions (RQ1a and RQ1b):

RQ1a: Which specific variables from the group factors of CS influence CS? 
This research question is based on published models where relationships have been established between CE, PQ and PV to CS (Fornell et al., 1996), complemented by a relationship of C to CS (Dubrovski, 2001) and relationship PK to CS (Johnson, Fornell, 1991, Wang, Hazen, 2016).

RQ1b: Which specific variables from the group PC and demographic characteristics influence CS?

This research question is based on established relationships of published models of relationship of demographic characteristics Age and Income to CS (Tarasi et al., 2013), complemented by a relationship of Sex to CS (Anderson et al., 2008). The second part of the research question that concerns PC is inspired by the relationships of these characteristics (namely Pers1 - Pers3) to financial satisfaction (Xiao et al., 2014) and relationships of Pers4 - Pers7 to life satisfaction (Ho et al., 2010, Prenda, Lachman, 2001, Peterson, Ekici, 2007).

In the other stages of the research, the authors examine the question of if and how the commonly mentioned psychological aspects of a customer's personality relate to the factors of CS.

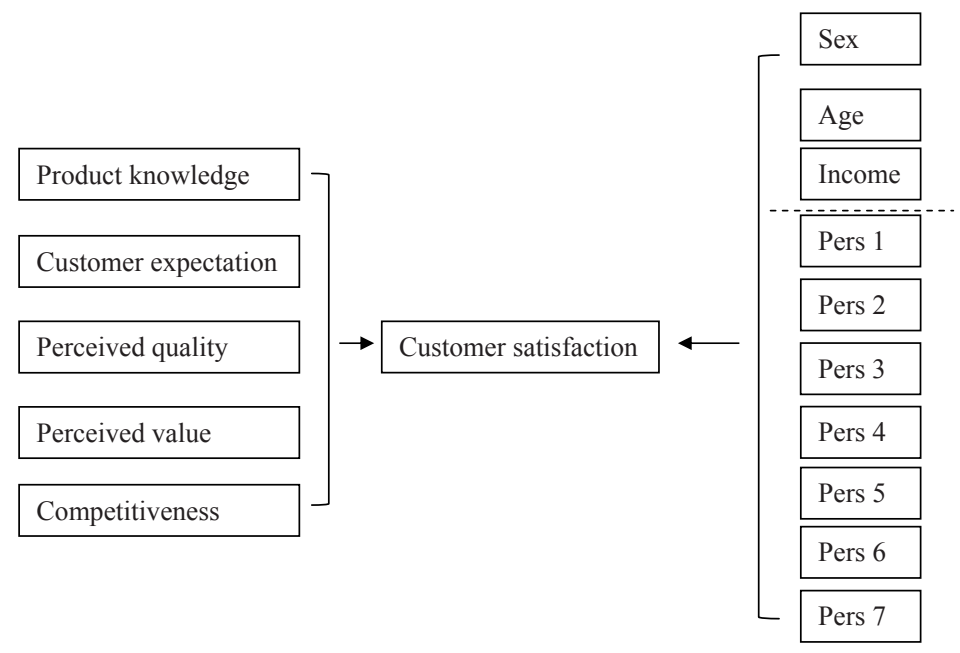

Fig. 2a-Model CS with respect to the factors of satisfaction, its demographic and personality characteristics. Source: authors

Fig. $2 \mathrm{~b}$ is used to illustrate the modelled association. Based on the model illustrated in Fig. 2b, a second research question (RQ2) can be formulated:

Which specific variables from the group of variables factors of CS are related to the specific variables from the group of variables PC?

This research question is based on the complexity of the mutual relationships of the individual variables in the model, resp. from the fact that different variables in one model interact (see Fornell et al., 1996, Anderson et al. 2008, Ho et al., 2010). 


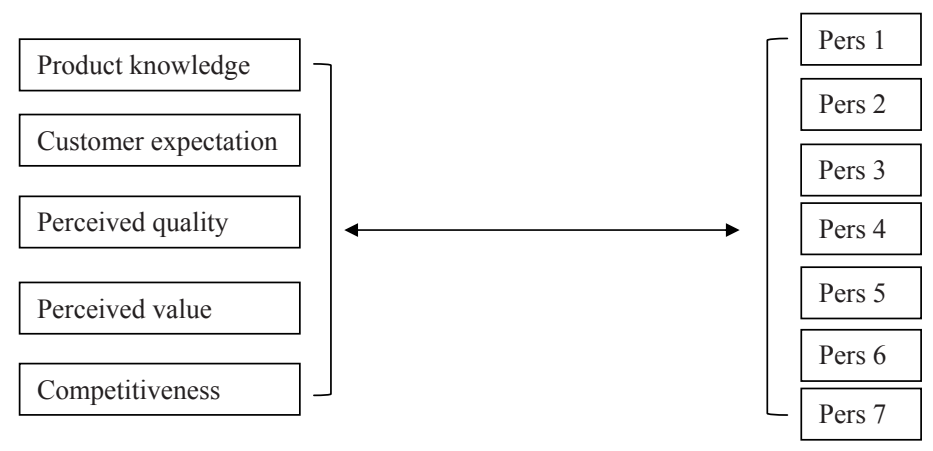

Fig. $2 b-$ Model of Factors of CS and its PC. Source: authors

\section{RESULTS}

In the first part of the research, CS was modelled using two groups of variables: factors of CS and PC and demographic characteristics, using two models. The results from both models are shown in Table 1a (Multiple Regression Analysis) and Table 1b (Hierarchical Mixed-effect Model Analysis).

Tab. 1a - Multiple Regression Analysis Model with all control variables. Source: authors

\begin{tabular}{|l|l|l|l|l|}
\hline & Estimate & Std. Error & t-value & $\operatorname{Pr}(>|\mathrm{t}|)$ \\
\hline (Intercept) & -0.0513976 & 0.1600911 & -0.321 & 0.748 \\
\hline PRODUCT_KNOWLEDGE & 0.0068663 & 0.0084194 & 0.816 & 0.415 \\
\hline CUSTOMER_EXPECTATION & 0.2179452 & 0.0245504 & 8.877 & $<2 \mathrm{e}-16$ \\
\hline PERCEIVED_QUALITY & 0.4782461 & 0.0258172 & 18.524 & $<2 \mathrm{e}-16$ \\
\hline PERCEIVED_VALUE & 0.3739445 & 0.0208377 & 17.946 & $<2 \mathrm{e}-16$ \\
\hline COMPETITIVENESS & -0.0314230 & 0.0221350 & -1.420 & 0.156 \\
\hline SEX & -0.0062867 & 0.0418307 & -0.150 & 0.881 \\
\hline INCOME & -0.0118621 & 0.0100622 & -1.179 & 0.239 \\
\hline AGE & -0.0001616 & 0.0012793 & -0.126 & 0.899 \\
\hline PERS1 - an adequate monthly income & -0.0051455 & 0.0078482 & -0.656 & 0.512 \\
\hline $\begin{array}{l}\text { PERS2 - access to the purchase of cheap } \\
\text { products }\end{array}$ & 0.0126755 & 0.0090289 & 1.404 & 0.161 \\
\hline $\begin{array}{l}\text { PERS3 - reserve for unexpected expendi- } \\
\text { ture }\end{array}$ & 0.0405196 & 0.0294739 & 1.375 & 0.169 \\
\hline PERS4 - the level of optimism & -0.0011065 & 0.0095660 & -0.116 & 0.908 \\
\hline PERS5 - fullness of the fridge & -0.0020479 & 0.0117559 & -0.174 & 0.862 \\
\hline PERS6 - frequency of shopping & 0.0001966 & 0.0088827 & 0.022 & 0.982 \\
\hline $\begin{array}{l}\text { PERS7 - customers' attitudes towards } \\
\text { marketing }\end{array}$ & -0.0054528 & 0.0070828 & -0.770 & 0.441 \\
\hline
\end{tabular}


The results show that overall customer satisfaction is significantly influenced by only three variables out of the group of factors of CS - CE, PQ and PV, all of which influence CS positively. The influence of the other variables, including the group of PC and demographic characteristics, were not statistically significant for overall customer satisfaction.

The Variance Inflation Factors (VIF) for all the variables in a multiple regression model were less than 10, therefore, the model is not affected by multicollinearity. In Table 2, we present the VIFs for the group of variables of PC, as these variables and their connections to the group of variables factors of CS will be addressed in the results in the second part of the research.

Tab. 2 - Variance Inflation Factors of the variables of 'personal characteristics'. Source: authors

\begin{tabular}{|l|l|l|l|l|l|l|l|}
\hline & PERS1 & PERS2 & PERS3 & PERS4 & PERS5 & PERS 6 & PERS7 \\
\hline VIF & 1.432606 & 1.192511 & 1.125379 & 1.130548 & 1.166800 & 1.122110 & 1.031515 \\
\hline
\end{tabular}

The traditional multiple regression model assumes the independence of cases (the customers in this research). As each of the 102 companies is always evaluated by a group of fifteen respondents (their customers), it cannot be assumed a priori that all 1,530 customers represent reciprocally independent cases. On the other hand, it is reasonable to consider whether there is an association between the respondents (customers) evaluating the same company, and, therefore, to divide all of the 1,530 cases into 102 clusters. This is why the authors included a multilevel mixed-effect model which would take into account this potential association within the 102 clusters through the random effect of the clusters. The effects of the explanatory variables remain fixed.

Tab. 1b - Hierarchical Mixed-effect Model analysis with all control variables. Source: authors

\begin{tabular}{|l|l|l|l|l|}
\hline & Value & Std. Error & t-value & p-value \\
\hline (Intercept) & -0.0469541 & 0.16026085 & -0.292986 & 0.7696 \\
\hline PRODUCT_KNOWLEDGE & 0.0070038 & 0.00846462 & 0.827421 & 0.4081 \\
\hline CUSTOMER_EXPECTATION & 0.2170516 & 0.02456458 & 8.835960 & 0.0000 \\
\hline PERCEIVED_QUALITY & 0.4790467 & 0.02587906 & 18.510977 & 0.0000 \\
\hline PERCEIVED_VALUE & 0.3734152 & 0.02086104 & 17.900122 & 0.0000 \\
\hline COMPETITIVENESS & -0.0311408 & 0.02218104 & -1.403936 & 0.1606 \\
\hline SEX & -0.0067383 & 0.04186900 & -0.160939 & 0.8722 \\
\hline INCOME & -0.0119982 & 0.01006341 & -1.192263 & 0.2334 \\
\hline AGE & -0.0001585 & 0.00128088 & -0.123768 & 0.9015 \\
\hline PERS1 - an adequate monthly income & -0.0051705 & 0.00784431 & -0.659146 & 0.5099 \\
\hline $\begin{array}{l}\text { PERS2 - access to the purchase of } \\
\text { cheap products }\end{array}$ & 0.0126620 & 0.00902833 & 1.402469 & 0.1610 \\
\hline $\begin{array}{l}\text { PERS3 - reserve for unexpected ex- } \\
\text { penditure }\end{array}$ & 0.0396877 & 0.02946618 & 1.346891 & 0.1782 \\
\hline PERS4 - the level of optimism & -0.0011784 & 0.00956491 & -0.123199 & 0.9020 \\
\hline PERS5 - fullness of the fridge & -0.0020774 & 0.01174950 & -0.176811 & 0.8597 \\
\hline
\end{tabular}




\begin{tabular}{|l|l|l|l|l|}
\hline PERS6 - frequency of shopping & 0.0000844 & 0.00887946 & 0.009509 & 0.9924 \\
\hline $\begin{array}{l}\text { PERS7 - customers' attitudes towards } \\
\text { marketing }\end{array}$ & -0.0052919 & 0.00708151 & -0.747281 & 0.4550 \\
\hline
\end{tabular}

The results of the mixed-effect model are shown in Table 1b and the value of the ICC for this model is 0.005363073 . This value can be interpreted as such that the influence of the cluster is very small, and, therefore, the mixed-effect model is not necessary. That is why it is not surprising to have the same interpretation of the results from the mixed-effect model as the non-hierarchical traditional multiple regression model shown in Table 1a. Once again, only the variables CE, PQ and PV have a significant influence for CS. The influence of the other variables, including the group of variables 'of demographic and personal characteristics' was, again, statistically insignificant.

The second part of the research discovered the association of the individual variables of the group factors of CS on the one hand, and the individual variables of the sub-group PC, on the other. The level of association of both sets of variables was assessed using the Canonical Correlation Analysis.

First, a correlation matrix was created (see Table 3) which indicates the values for the correlation coefficients in pairs between each CS factor and for every personal characteristic. From this correlation, it is possible to (roughly) conclude that the association between both sets will be small.

Tab. 3 - Correlation between pairs between each left-set variable (CS factors) with each variable of the right set (personal traits). Source: authors

\begin{tabular}{|c|c|c|c|c|c|c|c|}
\hline \multirow{2}{*}{$\mathrm{N}=1530$} & \multicolumn{7}{|c|}{ Correlations } \\
\hline & PERS1 & PERS2 & PERS3 & PERS4 & PERS5 & PERS6 & PERST \\
\hline $\begin{array}{l}\text { PRODUCT } \\
\text { KNOWLEDGE }\end{array}$ & -0.0334 & 0.0708 & 0.0323 & 0.0627 & 0.0309 & 0.0376 & 0.0433 \\
\hline $\begin{array}{l}\text { CUSTOMER } \\
\text { EXPECTATION }\end{array}$ & 0.0411 & 0.1624 & -0.0363 & 0.1463 & 0.0674 & 0.0286 & 0.1105 \\
\hline $\begin{array}{l}\text { PERCEIVED } \\
\text { QUALITY }\end{array}$ & 0.0646 & 0.1661 & -0.0365 & 0.1741 & 0.1035 & 0.0623 & 0.0615 \\
\hline $\begin{array}{l}\text { PERCEIVED } \\
\text { VALUE }\end{array}$ & 0.0638 & 0.2044 & -0.0042 & 0.1734 & 0.1247 & 0.0558 & 0.0591 \\
\hline $\begin{array}{l}\text { COMPETITIVE- } \\
\text { NESS }\end{array}$ & 0.0034 & 0.1686 & 0.0318 & 0.1404 & 0.1168 & 0.0506 & 0.0333 \\
\hline
\end{tabular}

Five pairs of canonical variables were then created representing the individual sets using the Canonical Correlation Analysis, and the corresponding canonical correlation coefficients were calculated for each pair of canonical variables. The overall redundancy for each of the sets was subsequently calculated. From the perspective of the research, the redundancy of the left set, which represents the group of variable factors of CS, was particularly interesting. This redundancy describes which part of CS (represented by all of the 5 variables from the group factors of CS at the same time) can be explained using the set of variables describing the PC from the 
sub-group of variables of PC. This redundancy was only $4.92 \%$. This shows that customer satisfaction is explained by the psychological aspects of personality by less than $5 \%$ (see Table 4 ).

Tab. 4 - Canonical Analysis Summary. Source: authors

\begin{tabular}{|c|l|l|}
\hline \multirow{2}{*}{$\mathrm{N}=1530$} & \multicolumn{2}{l|}{$\begin{array}{l}\text { Canonical R: } 0.27393 \\
\text { Chi2(35)=195.08 } \mathrm{p}=0.0000\end{array}$} \\
\cline { 2 - 3 } & Left set & Right set \\
\hline Number of variables & 5 & 7 \\
\hline Variance extracted & $100.000 \%$ & $74.0503 \%$ \\
\hline Total redundancy & $4.91672 \%$ & $2.25532 \%$ \\
\hline Variables 1 & PK & PERS1 - adequate monthly income \\
\hline 2 & CE & PERS2 - access to the purchase of cheap products \\
\hline 3 & PQ & PERS3 - reserve for unexpected expenditure \\
\hline 4 & PV & PERS4 - the level of optimism \\
\hline 5 & C & PERS5 - fullness of the fridge \\
\hline 6 & & PERS6 - frequency of shopping \\
\hline 7 & & PERS7 - customers' attitudes towards marketing \\
\hline
\end{tabular}

Although redundancy is very small, the first three of the five canonical correlation coefficients are statistically significant at a significance level of 5\% (see Table 5):

First canonical coefficient $\mathrm{R}(\mathrm{C}) 1=0.2739$

Second canonical coefficient $\mathrm{R}(\mathrm{C}) 2=0.1737$

Third canonical coefficient $\mathrm{R}(\mathrm{C}) 3=0.120028$

Tab. 5 - Canonic coefficients. Source: authors

\begin{tabular}{|l|l|l|l|l|l|l|}
\hline \multirow{2}{*}{$\begin{array}{l}\text { Root Re- } \\
\text { moved }\end{array}$} & \multicolumn{6}{l}{ Chi-Square Tests with Successive Roots Removed } \\
\cline { 2 - 7 } & Canonic. R & $\begin{array}{l}\text { Canonic. } \\
\text { R-sqr. }\end{array}$ & Chi-sqr. & df & p & $\begin{array}{l}\text { Lambda } \\
\text { prime }\end{array}$ \\
\hline 0 & 0.273928 & 0.075037 & 195.0808 & 35 & 0.000000 & 0.879737 \\
\hline 1 & 0.173739 & 0.030185 & 76.3238 & 24 & 0.000000 & 0.951105 \\
\hline 2 & 0.120028 & 0.014407 & 29.6588 & 15 & 0.013244 & 0.980708 \\
\hline 3 & 0.063702 & 0.004058 & 7.5650 & 8 & 0.477087 & 0.995044 \\
\hline 4 & 0.030037 & 0.000902 & 1.3743 & 3 & 0.711577 & 0.999098 \\
\hline
\end{tabular}

Therefore, although these sets are not well connected, there is a statistically significant association through the first three pairs of canonical correlation coefficients. However, the first canonical pair is particularly relevant for further interpretation. Out of the total redundancy breakdown of $4.9167 \%, 4.49 \%$ of the value come from the first pair of canonical representatives. For more, see Table 6. 
Tab. 6 - Decomposing the overall redundancy of "customer satisfaction factors" set into individual canonical couples. Source: authors

\begin{tabular}{|l|l|l|}
\hline \multirow{2}{*}{ Factor } & \multicolumn{2}{|l|}{ Variance Extracted (Proportions), left set } \\
\cline { 2 - 3 } & Variance exctracted & Redundancy \\
\hline Root 1 & 0.598423 & 0.044904 \\
\hline Root 2 & 0.077376 & 0.002336 \\
\hline Root 3 & 0.075027 & 0.001081 \\
\hline Root 4 & 0.197138 & 0.000800 \\
\hline Root 5 & 0.052037 & 0.000047 \\
\hline
\end{tabular}

Therefore, we will subsequently concentrate only on the first pair of canonical representatives from both sets. As the canonical correlation of this first pair is significant and has a positive value $(\mathrm{R}(\mathrm{C}) 1=0.2739)$, in simple terms it can be stated that greater CS is linked to greater life and financial satisfaction. This interpretation is possible because, as was the case with the first canonical representative of the set of factors of satisfaction, so the first canonical representative of the set of PC is linked positively to all of the variables of their sets, as can be seen in Table 7 .

Tab. 7 - Correlation between the individual members of a set of satisfaction factors and a representative of the set and a set of personality characteristics and a representative of the set. Source: authors

\begin{tabular}{|l|l|l|l|}
\hline Factors & $\begin{array}{l}\text { First canonical } \\
\text { variable, left set }\end{array}$ & Factors & $\begin{array}{l}\text { First canonical variable, } \\
\text { right set }\end{array}$ \\
\hline PK & 0.365602 & PERS1 - adequate monthly income & 0.22084 \\
\hline CE & 0.755680 & $\begin{array}{l}\text { PERS2 - access to the purchase of } \\
\text { cheap products }\end{array}$ & 0.766942 \\
\hline PQ & 0.829597 & $\begin{array}{l}\text { PERS3 - reserve for unexpected } \\
\text { expenditure }\end{array}$ & 0.005043 \\
\hline PV & 0.955258 & PERS4 - the level of optimism & 0.659661 \\
\hline C & 0.828644 & PERS5 - fullness of the fridge & 0.515331 \\
\hline & & PERS6 - frequency of shopping & 0.216286 \\
\hline & & $\begin{array}{l}\text { PERS7 - customers' attitudes to- } \\
\text { wards marketing }\end{array}$ & 0.158795 \\
\hline
\end{tabular}

All of the values in the first column of Table 7 are positive, and the correlation coefficients with the variables PV, PQ, C and CE are particularly high. All of the values in the last column of Table 7 are also positive, in particular the correlation coefficients with the variable quantities Pers2 (representing financial capacity), Pers4 (representing the level of optimism) and Pers5 (representing the level of planning) are large. Therefore, the canonical correlation between both sets of variables is caused by the variables PV, PQ, C and CE on the one hand, and the variables Pers2, Pers 4 and Pers 5 on the other.

On the basis of the canonical correlation model, it can be concluded that both sets - the factors 
of CS and PC - are directly linked very weakly, albeit significantly. Fig. 3 shows the resulting model on the basis of the association of both the above-mentioned parts of the research results. It is clear that there are PC which jointly influence (albeit weakly) the common factors of CS, which are further independently projected onto their own (general) CS with the company.

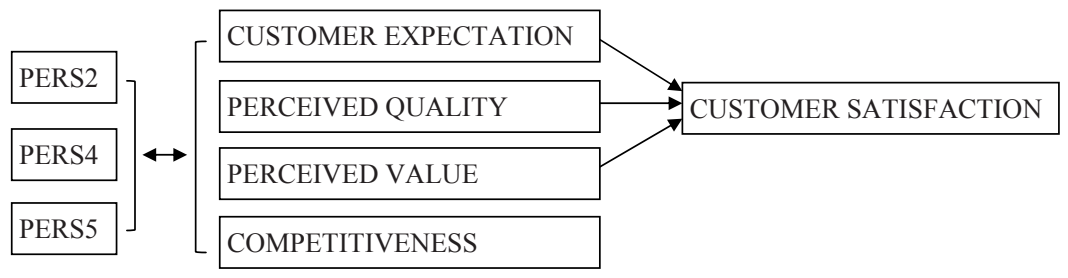

Fig. 3 - Plausible findings based on separate models of multiple regression and canonical correlation. Source: authors

\section{DISCUSSION AND CONCLUSION}

The first section of the research tested the relationship between CS and the factors which could influence it. It was determined that CS was influenced by three factors: CE, PQ and PV. This finding is in line with international research in this area if research which used similar variables (cf. Fornell et al., 1996), or which referred at least in part to similar products (see Martensen et al., 2000) is compared. In this regard, the results are not surprising.

What is more interesting is that CS is not influenced by any of the variables from the group of personal and demographic characteristics. On the other hand, a connection between the variables of age and gender and CS were demonstrated in the automotive industry (Mittal \& Kamakura, 2001), in services (Gilbert \& Veloutsou, 2006), and, finally, weakly in organic products (food industry), with the latter also including the variable of income (Tsakiridou et al., 2008).

One explanation may be the absence of a direct relationship between demographic characteristics and CS (not only in the case of the food industry). There is a general lack of research into the food industry, with the majority of studies (particularly in relation to services) dealing with the moderating effect of demographic characteristics on the links between CS and other variables, either on the links with variables which influence CS (see, e.g. Anderson et al., 2008), or on the links with variables which, contrastingly, are influenced by CS (see, e.g. Cooil et al., 2007). Some studies show only a weak direct influence of these characteristics on CS (Tsakiridou et al., 2008).

The authors did not find any research studies on the relationship between the majority of PC (with the exception of the attitude of customers towards advertising - variable Personality 7) and CS, which means that either no research exists or that the relationship between these types of variables has not been proven. For an example of the latter, no relationship was shown between the level of optimism and CS concerning one product in the automotive and footwear industries (Westbrook, 1980). Our research showed no relationship between certain PC and CS.

Regarding customer attitudes towards advertising, our result did not entirely correspond with the results of other research (Chan, Cui, 2004). One reason for this could be the shift of the 
Czech Republic from the group of transitional to the group of mature economies, where the influence of customer attitude towards advertising on CS was not proven due to customers' increased level of criticism. In terms of GDP per capita, the Czech Republic is comparable to Malta, Greece and Portugal (cf. Rodrigues, 2017). Therefore, the Czech Republic cannot compare with the most advanced global economies, though it is necessary to take into consideration the positive influence from its membership of the European Union since 2004 and the relatively long period of transformation in the 1990s. It is clear that the Czech Republic can no longer be described as a transitional economy.

The second part of the research tested the relationship between the group of CS variables and the group of PC variables. It was determined that there exists a weak positive association between these groups. The reason for the positive association between these two groups lies with the variables PV, PQ, C and CE from the group factors of CS, Pers2 (representing financial capital), Pers4 (representing the level of optimism), and Pers5 (representing the level of planning) from the group of PC. It was, therefore, possible to show that there exists a relationship between the factors which demonstrably influence other types of satisfaction and the factors which influence CS. This indicates a mutual relationship for the different types of satisfaction through the factors which satisfaction influences and thus the results confirm the accuracy of the relationships indicated in diagram 1.

It is interesting that once again no relationship was proven between the variable of customer attitude towards advertising (Pers7), as part of the group of variables PC, and the group of variables factors of CS. The question arises as to whether the reason for this result is indeed the high level of criticism, i.e. the correct perception of advertising which properly adjusts and rationalizes the advertisement's message, or whether the customer is not conscious of the influence of advertising.

Although the regressive model did not show a significant direct effect of personal and demographic characteristics and certain customer satisfaction variables on CS, it did show a weak relationship between the groups of variables factors of CS and PC. This is mainly due to particular variables which CS demonstrably influences along with certain variables of PC which, again, demonstrably influence other forms of satisfaction. Specifically, financial capacity influences financial satisfaction, while the level of optimism and the level of planning influence life satisfaction. Therefore, all three kinds of satisfaction could be linked though partial variables.

The research also has practical implications for food business enterprises, as it has been demonstrated that certain other characteristics of the customer are combined with his / her satisfaction or more precisely factors that affect it. These characteristics can affect the satisfaction of the customer in order to increase satisfaction and the revenue (performance) of the company. It can be deduced that the customer does not want to buy cheap products (Pers2), is rather optimistic (Pers4) and wants to buy goods in a smaller volume (Pers5). Therefore, the production and sale of more expensive products, either of higher product lines, products with organic attributes, or products bearing the label quality can be recommended to enterprises. At the same time, companies should not focus on selling more goods (discounts on buying more than $2+1$ for free), but on the sale of individual (more expensive) pieces. Optimal customer tuning can then be used to offer new or upgraded products, as optimists can be expected to be more willing to 
buy novel products (compare with Desouza et al., 2008). At the same time, it is advisable to use the optimistic customer base in communications with the customer, e.g. in advertising, packing politics, etc.

\section{Acknowledgements}

This article is an output of the project Czech Science Foundation no. GA 16-16260S. "Přístup managementu k redukci zpětných tokủ ve vazbě na spokojenost zákazníků a neustálé zlepšování.”

\section{References}

1. Aaker D. A. (1991). Managing Brand Equity. The Free Press. New York.

2. Aghamirian, B., Dorri, B., \& Aghamirian, B. (2015). Customer knowledge management application in gaining organization's competitive advantage in electronic commerce. Journal of theoretical and applied electronic commerce research, 10 (1), 63-78. http://dx.doi.org/10.4067/ S0718-18762015000100006

3. Anderson, S., Pearo, L. K. \& Widener, S. K. (2008). Drivers of service satisfaction: linking customer satisfaction to the service concept and customer characteristics. Journal of Service Research, 10 (4), 365-381. https://doi.org/10.1177/1094670508314575

4. Azizli, N., Atkinson, B. E., Baughman, H. M. \& Giammarco, E. A. (2015). Relationships between general self-efficacy, planning for the future, and life satisfaction. Personality and Individual Differences, 82, 58-60. https://doi.org/10.1016/j.paid.2015.03.006

5. Brunsø K., Fjord T. A. \& Grunert, K. G. (2002). Consumers' food choice and quality perception. MAPP working paper 77. Aarhus: Aarhus School of Business.

6. Cardello, A. V. (1995). Food quality: relativity, context and consumer expectations. Food quality and preference, 6 (3), pp. 163-170. https://doi.org/10.1016/0950-3293(94)00039-X

7. Chan, T. S. \& Cui, G. (2004). Consumer attitudes toward marketing in a transitional economy: a replication and extension. Journal of Consumer Marketing, 21(1), 10-26. https://doi. org/10.1108/07363760410513932

8. Chen, C. C., Huang, W. J. \& Petrick, J. F. (2016). Holiday recovery experiences, tourism satisfaction and life satisfaction-Is there a relationship? Tourism Management, 53, 140-147. https://doi.org/10.1016/j.tourman.2015.09.016

9. Cooil, B., Keiningham, T. L., Aksoy, L. \& Hsu, M. (2007). A longitudinal analysis of customer satisfaction and share of wallet: Investigating the moderating effect of customer characteristics. Journal of marketing, 71 (1), 67-83. https://doi.org/10.1509/jmkg.71.1.67

10. Desouza, K. C. \& Awazu, Y. (2005). What do they know? Business strategy review, 16 (1), 41-45. https://doi.org/10.1111/j.0955-6419.2005.00351.x

11. Desouza, K. C., Awazu, Y., Jha, S., Dombrowski, C., Papagari, S., Baloh, P., \& Kim, J. Y. (2008). Customer-driven innovation. Research-Technology Management, 51 (3), 35-44. https:// doi.org/10.1080/08956308.2008.11657503

12. Dubrovski, D. (2001). The role of customer satisfaction in achieving business excellence. Total quality management, 12 (7-8), 920-925. https://doi.org/10.1080/09544120100000016

13. Dixon, A. L. \& Schertzer, S. M. (2005). Bouncing back: How salesperson optimism and self-efficacy influence attributions and behaviors following failure. Journal of Personal Selling \& Sales Management, 25 (4), 361-369. 
14. Edvardsson, B. \& Olsson, J. (1996). Key concepts for new service development. Service Industries Journal, 16 (2), 140-164. https://doi.org/10.1080/02642069600000019

15. El-Diraby, T. E., Costa, J. \& Singh, S. (2006). How do contractors evaluate company competitiveness and market attractiveness? The case of Toronto contractors. Canadian Journal of Civil Engineering, 33 (5), 596-608. https://doi.org/10.1139/106-017

16. Floh A., Zauner A., Koller M. \& Rusch T. (2014): Customer segmentation using unobserved heterogeneity in the perceived-value-loyalty-intentions link. Journal of Business Research, 67 (5), 974-982. https://doi.org/10.1016/j.jbusres.2013.08.003

17. Fornell, C. (1992). A national customer satisfaction barometer: The Swedish experience. The Journal of Marketing, 56 (1), 6-21. https://doi.org/10.2307/1252129

18. Fornell, C., Johnson, M. D., Anderson, E. W., Cha, J. \& Bryant, B. E. (1996). The American customer satisfaction index: nature, purpose, and findings. The Journal of Marketing, 7-18. https://doi.org/10.2307/1251898

19. Gelman, A., \& Hill, J. (2006). Data analysis using regression and multilevel/hierarchical models. Cambridge university press. New York.

20. Gilbert, G. R., \& Veloutsou, C. (2006). A cross-industry comparison of customer satisfaction. Journal of Services Marketing, 20 (5), 298-308. https://doi.org/10.1108/08876040 610679918

21. Grunert K. G. (2005). Food quality and safety: consumer perception and demand. European Review of Agricultural Economics, 32 (3), 369-391. https://doi.org/10.1093/eurrag/jbi011

22. Haghirian, P., \& Madlberger, M. (2005). Consumer attitude toward advertising via mobile devices-An empirical investigation among Austrian users. ECIS 2005 Proceedings, 44-57.

23. Henning-Thurau, \& T. \& Klee, A. (1997). The impact of customer satisfaction and relationship quality on customer retention: a critical reassessment and model development. Psychology and Marketing, 14 (8), 737-764.

24. Ho, M. Y., Cheung, F. M., \& Cheung, S. F. (2010). The role of meaning in life and optimism in promoting well-being. Personality and individual differences, 48 (5), 658-663. https://doi. org/10.1016/j.paid.2010.01.008

25. Hofmann, W., Luhmann, M., Fisher, R. R., Vohs, K. D., \& Baumeister, R. F. (2014). Yes, but are they happy? Effects of trait self-control on affective well-being and life satisfaction. Journal of Personality, 82 (4), 265-277. https://doi.org/10.1111/jopy.12050

26. Johnson, M. D., \& Fornell, C. (1991). A framework for comparing customer satisfaction across individuals and product categories. Journal of economic psychology, 12, 267-286. http:// dx.doi.org/10.1016/0167-4870(91)90016-M

27. Lent, R. W., Singley, D., Sheu, H. B., Gainor, K. A., Brenner, B. R., Treistman, D., \& Ades, L. (2005). Social cognitive predictors of domain and life satisfaction: Exploring the theoretical precursors of subjective well-being. Journal of counseling psychology, 52 (3), 429-442. http://dx.doi.org/10.1037/0022-0167.52.3.429

28. Martensen, A., Gronholdt, L., \& Kristensen, K. (2000). The drivers of customer satisfaction and loyalty: cross-industry findings from Denmark. Total Quality Management, 11 (4-6), 544-553. https://doi.org/10.1080/09544120050007878 
29. Mittal, V., \& Kamakura, W. A. (2001). Satisfaction, repurchase intent, and repurchase behavior: Investigating the moderating effect of customer characteristics. Journal of marketing research, 38 (1), 131-142. https://doi.org/10.1509/jmkr.38.1.131.18832

30. Monroe K. B. (2002). Pricing: Making Profitable Decisions. 3rd (Ed.). McGraw-Hill Book Company. New York.

31. Neal, J. D., \& Gursoy, D. (2008). A multifaceted analysis of tourism satisfaction. Journal of Travel Research, 47 (1), 53-62. https://doi.org/10.1177/0047287507312434

32. Neal, J. D., Uysal, M., \& Sirgy, M. J. (2007). The effect of tourism services on travelers' quality of life. Journal of Travel Research, 46 (2), 154-163. https://doi.org/10.1177/0047287507 303977

33. Ojasalo, J. (2001). Managing customer expectations in professional services. Managing Service Quality: An International Journal, 11 (3), 200-212. https://doi.org/10.1108/09604520110391379

34. Ophuis P. A. O., \& Van Trijp H. C. (1995): Perceived quality: A market driven and consumer oriented approach. Food quality and Preference. 6 (3), 177-183. https://doi. org/10.1016/0950-3293(94)00028-T

35. Peterson, M., \& Ekici, A. (2007). Consumer attitude toward marketing and subjective quality of life in the context of a developing country. Journal of Macromarketing, 27 (4), 350-359. https://doi.org/10.1177/0276146707307125

36. Poulsen C. S., Juhl H. J., Kristensen K., Bech A. C., \& Engelund E. (1996). Quality guidance and quality formation. Food Quality and Preference. 7 (2), 127-155. https://doi. org/10.1016/0950-3293(95)00044-5

37. Prenda, K. M., \& Lachman, M. E. (2001). Planning for the future: a life management strategy for increasing control and life satisfaction in adulthood. Psychology and aging, 16 (2), 206-216. https://doi.org/10.1037//0882-7974.16.2.206

38. Raudenbush, S. W., \& Bryk, A. S. (2002). Hierarcbical linear models: Applications and data analysis methods. Sage Publications. Thousand Oaks.

39. Rodrigues, M. D. S. (2017). The effects of income and public redistributive policies on income poverty control: a stochastic frontier approach for the EU 28 (Doctoral dissertation).

40. Spiteri, J. M., \& Dion, P. A. (2004). Customer value, overall satisfaction, end-user loyalty, and market performance in detail intensive industries. Industrial Marketing Management, 33 (8), 675-687. https://doi.org/10.1016/j.indmarman.2004.03.005

41. Sweeney, J. C., \& Soutar, G. N. (2001). Consumer perceived value: The development of a multiple item scale. Journal of retailing, 77 (2), 203-220. https://doi.org/10.1016/S00224359(01)00041-0

42. Tarasi, C. O., Bolton, R. N., Gustafsson, A., \& Walker, B. A. (2013). Relationship characteristics and cash flow variability: implications for satisfaction, loyalty, and customer portfolio management. Journal of Service Research, 16 (2), 121-137. https://doi.org/10.1177/10 94670512465958

43. Taylor, M. (2011). Measuring financial capability and its determinants using survey data. Social Indicators Research, 102 (2), 297-314. https://doi.org/10.1007/s11205-010-9681-9 
44. Tsakiridou, E., Boutsouki, C., Zotos, Y., \& Mattas, K. (2008). Attitudes and behaviour towards organic products: an exploratory study. International Journal of Retail \& Distribution Management, 36 (2), 158-175. https://doi.org/10.1108/09590550810853093

45. Tuorila, H., Cardello, A. V., \& Lesher, L. L. (1994). Antecedents and consequences of expectations related to fat-free and regular-fat foods. Appetite, 23 (3), 247-263. https://doi. org/10.1006/appe.1994.1057

46. Vera-Toscano, E., Ateca-Amestoy, V., \& Serrano-Del-Rosal, R. (2006). Building financial satisfaction. Social Indicators Research, 77 (2), 211-243. https://doi.org/10.1007/s11205-005$2614-3$

47. Wang, Y., \& Hazen, B. T. (2016). Consumer product knowledge and intention to purchase remanufactured products. International Journal of Production Economics, 181, 460-469. https:// doi.org/10.1016/j.ijpe.2015.08.031

48. Westbrook, R. A. (1980). Intrapersonal affective influences on consumer satisfaction with products. Journal of consumer research, 7 (1), 49-54. https://doi.org/10.1086/208792

49. Woodruff, R., \& Gardial S. F. (1996). Know Your Customer: New Approaches to Understanding Customer Value and Satisfaction. Blackwell. Malden.

50. Xiao, J. J., Chen, C., \& Chen, F. (2014). Consumer financial capability and financial satisfaction. Social Indicators Research, 118 (1), 415-432. https://doi.org/10.1007/s11205-0130414-8

51. Yang Z., \& Peterson R. T. (2004). Customer perceived value, satisfaction, and loyalty: The role of switching costs. Psychology \& Marketing. 21 (10), 799-822. https://doi.org/10.1002/ mar.20030

52. Zeithaml V. A. (1988). Consumer perceptions of price, quality, and value: a meansend model and synthesis of evidence. Journal of Marketing. 52 (3), 2-22. https://doi. $\operatorname{org} / 10.2307 / 1251446$

\section{Contact information}

assoc. prof. Ing. Suchanek Petr, Ph.D.

Masaryk University Brno

Faculty of Economics and Administration

Department of Corporate Economy

Czech Republic

E-mail:suchy@econ.muni.cz.

Mgr. Kralova Maria, Ph.D.

Masaryk University Brno

Faculty of Economics and Administration

Department of Corporate Economy

Czech Republic

E-mail:kralova@econ.muni.cz. 


\section{Appendix}

\begin{tabular}{|l|l|}
\hline Factor & Characteristic \\
\hline PK & $\begin{array}{l}\text { Customer knowledge is about products, suppliers and markets and customer } \\
\text { trends and future needs, and ideas for product innovations }\end{array}$ \\
\hline CE & Customer expectation is based on the customer's needs and wishes \\
\hline PQ & $\begin{array}{l}\text { The customer's perception of the overall quality or superiority of the product } \\
\text { or service with respect to its intended purpose, relative to the alternatives }\end{array}$ \\
\hline PV & $\begin{array}{l}\text { Perceived value is the result of the personal comparison between perceived } \\
\text { overall benefits and the perceived sacrifices or costs paid by the customer }\end{array}$ \\
\hline C & $\begin{array}{l}\text { Competitiveness refers to ability to design, produce and market products } \\
\text { superior to those offered by competitors, considering the price and non-price } \\
\text { qualities }\end{array}$ \\
\hline CS & $\begin{array}{l}\text { Customer Satisfaction is the overall experience with a purchase, as general } \\
\text { satisfaction }\end{array}$ \\
\hline SEX & Gender of a customer (male / female) \\
\hline INCOME & Average monthly net income of a customer (in CZK) \\
\hline AGE & Age of a customer \\
\hline PERS1 & Adequacy of monthly income of a customer \\
\hline PERS2 & Access to the purchase of cheap products of customer \\
\hline PERS3 & Financial reserve for unexpected expenditure for three months of a customer \\
\hline PERS4 & The level of optimism of a customer \\
\hline PERS5 & Fullness of the fridge of a customer \\
\hline PERS6 & Frequency of shopping of a customer \\
\hline PERS7 & $\begin{array}{l}\text { Customers' attitudes (the level of criticism) towards marketing (specifically } \\
\text { advertising) }\end{array}$ \\
\hline
\end{tabular}

